\title{
The use of vascularised bone capping to prevent and treat amputation stump spiking in the paediatric population.
}

\author{
Adrian D Murphy ${ }^{1}$ \\ Sara E Atkins ${ }^{2}$ \\ Damon J Thomas ${ }^{1}$ \\ David McCombe ${ }^{1}$ \\ Chris J Coombs ${ }^{1}$ \\ 1. Dept of Plastic \& Maxillofacial Surgery, \\ Royal Children's Hospital, \\ Melbourne, \\ Victoria 3052, \\ Australia \\ 2. Dept. of Plastic \& Reconstructive Surgery, \\ John Radcliffe Hospital, \\ Oxford, \\ United Kingdom
}

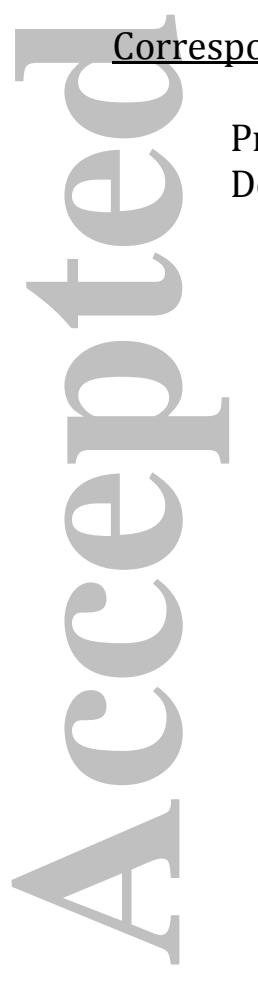

Prof. Chris J Coombs,

Dept of Plastic \& Maxillofacial Surgery, Royal Children's Hospital, Melbourne, Victoria 3052, Australia

Chris.coombs@rch.org.au

$+61-3-9345-6583$

This is the author manuscript accepted for publication and has undergone full peer review but has not been through the copyediting, typesetting, pagination and proofreading process, which may lead to differences between this version and the Version record. Please cite this article as doi:10.1002/ micr.30160. 


\section{The use of vascularised bone capping to prevent and treat amputation stump spiking in the paediatric population.}

\section{Abstract:}

Background

Overgrowth of the stump skeleton is a major complication seen in children after an amputation. In advanced cases, perforation of the bone spike through the skin can occur. Many surgical treatments have been employed to treat and prevent this, with best results seen when non-vascularised osteo-chondral bone grafts are placed to try to mimic a trans-articular amputation. We reviewed our outcomes using vascularized bone flaps to prevent and treat spiking.

Patients and Methods

Between 2000 and 2016 we carried out 6 vascularised osteo-cartilaginous bone capping procedures. Five patients underwent the procedure as an adjunct to primary amputation and in a single patient it was used to treat established bone spiking. Trauma accounted for three cases, with the other three being tumour, vascular malformation and ischemia. Three patients had pedicled bone flaps placed on the amputation stump and three underwent free tissue transfer (free calcaneus, free scapular angle, and free proximal tibia). Five cases involved lower limb amputations, with one in the upper limb.

\section{Results}

One patient had an early post-operative complication in the form of partial skin flap necrosis that required debridement and skin grafting. All bone flaps survived. Mean follow-up was 6.5 years. All patients had bony union with no development of stump spiking. Two patients required further procedures unrelated to the bone flaps.

Conclusion

Vascularised bone flaps to cap amputation stumps may be a safe and effective method of preventing and treating long-bone stump spiking following amputation in children

Keywords: $\quad$ amputation, children, overgrowth, stump, capping, epiphysis, bone transfer 
Introduction:

Overgrowth of the stump skeleton is the major complication seen in children after an amputation. Prevalence varies widely in different series, ranging from $4 \%$ to $86 \%$, with the prevalence decreasing as children get older, and after skeletal maturity it is exceptionally rare. It appears most frequently in the humerus, fibula, tibia and femur ${ }^{1-3}$.

This bony overgrowth is characterized by swelling, warmth, and tenderness at the amputation stump, and in many cases by the formation of a bursa over the bony spike. In advanced cases, perforation of the bone spike through the skin can occur. When this occurs there is difficulty with using an end-bearing prosthesis. Clinical diagnosis may be confirmed radiologically with a characteristic distal tapering of the bone to a narrow tip seen on x-ray.

Overgrowth is often recurrent, and may require multiple revision operations ${ }^{4-6}$.

Surgical strategies aimed at correcting this problem are multiple and may be broadly divided into those correcting established overgrowth and those attempting to prevent it at the time of primary amputation. Amputation overgrowth is considered to be a malfunction of normal fracture healing and growth mechanisms occurring at the amputated end of the bone ${ }^{4}$. Occlusion or plugging of the medullary canal appears to significantly retard these processes.

Initial clinical management of stump spiking includes prosthetic or lifestyle adjustments, followed by operative revision if signs or symptoms persist. Reported surgical strategies used to treat terminal osseous overgrowth once it has occurred include simple excision ${ }^{2-5}$; the use of silicone 7 , polyethylene or Teflon caps ${ }^{8}$; modifications of the Ertl tibiofibular osteomyoplasty ${ }^{9}$; calcaneo-cutaneous pedicle flaps ${ }^{10}$; as well as vascularised and non-vascularised bone capping 4,11-13.

Stump capping with osteocartilaginous grafts appears to be the most effective treatment for stump spiking. Vascularized bone flaps have been shown to be superior to non-vascularized grafts in the setting of scaphoid ${ }^{14}$, mandible ${ }^{15}$ and hip reconstruction ${ }^{16}$. For this reason we elected to use vascularized bone flaps in our series. This technique has previously only been reported in two cases of congenital pseudarthrosis of the tibia ${ }^{10}$, without long-term follow-up. We describe a case series of 6 patients treated with vascularized autologous bone to cap amputation stumps. Long-term function and radiological stump appearance is reported.

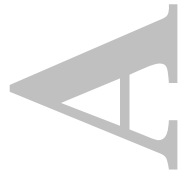


Patients and Methods:

This report was a retrospective review of a case series and was reviewed and approved by our institution's research review board. We reviewed the medical records of all children who underwent placement of a vascularised autologous osteo-cartilaginous cap to prevent or treat osseous overgrowth of an amputation stump at a single pediatric tertiary care hospital from $2000-2016$.

We carried out 6 vascularised osteo-cartilaginous bone capping procedures. Demographics are outlined in Table 1. Five patients underwent the procedure as an adjunct to primary amputation and in a single patient it was used to treat established stump spiking. The mean age of the patients at the time of the capping procedure was 9 years 10 months (range 7 years to 13 years 2 months). Trauma accounted for 3 cases, with the other 3 being tumour, vascular malformation and ischemia.

\section{Surgical techniques:}

Three patients had pedicled bone flaps placed on the amputation stump and three underwent free tissue transfer. Five cases involved lower limb amputations, with one in the upper limb.

Of the two lower limb pedicled vascularised osteo-cartilaginous cap procedures one was in the setting of trauma, the other in a patient with Factor $\mathrm{V}$ Leiden deficiency with non-salvageable distal ischemia. In the trauma setting a patient with a Symes amputation, a fillet foot flap was used to provide soft tissue cover to the amputation stump and the vascularised talus was used to cap the fibula. In a patient with amputation at mid-radius and ulna level, the distal radius epiphysis and metaphysis supplied by the anterior interosseous and radial artery was used to cap the end of the radial osteotomy.

Two patients underwent free vascularised osteo-cartilaginous flaps for prevention of overgrowth in primary amputations; one elective and on in the trauma setting. The trauma patient had the amputation stump covered by a free calcaneus and sole fillet composite flap that was fixed to the end of the tibia with a cancellous screw. The flap was vascularised using the anterior tibial vessels end to end on to the posterior tibial vessels. In the case of an osteosarcoma of the distal metaphysis of the femur, we used the tibia, distal to the tumour to provide an amputation stump of adequate length to facilitate prosthesis wear and ambulation (Fig. 1).

In a patient where the tibia had grown through the skin envelope and developed chronic osteomyelitis at 9 years after a below knee amputation, we managed with an osseomusculocutaneous latissimus dorsi with the scapula angle free flap. 


\section{$\underline{\text { Results: }}$}

Five patients had an uncomplicated post-operative course with no acute wound healing problems. One trauma patient who underwent a free calcaneus and fillet of sole flap required operative debridement and skin grafting for partial skin flap necrosis.

The bone flaps survived in all patients, and all 6 achieved clinical and radiological bony union facilitating prosthesis use.

One patient, 16 years after a free fillet foot flap with calcaneus, had radiological evidence of fibular overgrowth, but this was not clinically evident, and did not cause pain or discomfort or interfere with the ability to wear a prosthesis. A second patient required further surgery in the form of removal of metalwork and hemi-epiphyseodesis for medial malleolar overgrowth. There was no clinical or radiological evidence of fibular overgrowth however, where the vascularized bone flap had been placed.

The single case where a free scapular flap was used to treat established stump spiking at 4 years of follow up had no further stump problems or signs of overgrowth.

Mean follow-up period was 6.5 years (range 3.5 years to 16 years). All 6 patients had stable amputation stumps with no clinically evident stump spiking. All could wear prosthesis and had good function.

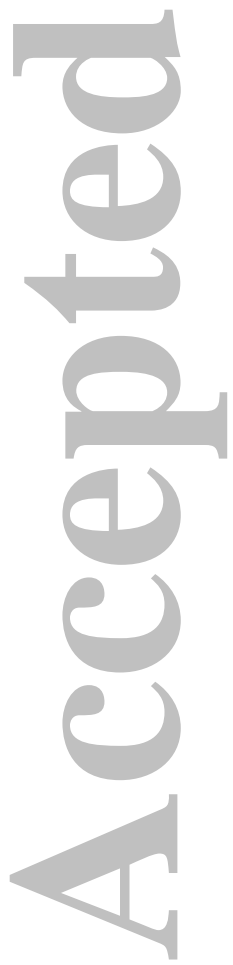




\section{Case Reports:}

\section{Case 1:}

The single upper limb case was an 8-year-old boy who had underwent multiple previous debulking procedures for a large lympho-venous malformation of the left forearm and hand (Fig. 2a). Despite these procedures the patient had poor function in the hand, persistent pain and recurrent infections and the decision was taken to proceed to amputation. Amputation was carried out at mid-radius and ulna level. The distal radius epiphysis and metaphysis, including the growth plate, was maintained on the anterior

interosseous and radial artery blood supply and used to cap the end of the radial osteotomy (Fig. 2b). The patient's immediate post-operative course was uneventful. Clinically and radiologically the flap has survived. At 4 years follow up the patient has had no stump problems, no clinical or radiological evidence of overgrowth. X-ray at one year post-operatively shows growth from the distal radial epiphysis with $6 \mathrm{~mm}$ of growth seen (Fig. 2c).

Case 2:

A 9-year-old girl presented with an osteosarcoma of the distal metaphysis of the femur. Resection would result in a high level above knee amputation and the family deemed rotationplasty unacceptable. As an alternative we proposed using an inverted, reversed proximal tibial free flap.

Skin and muscle flaps were raised though a transverse incision at the knee with distal medial and lateral extensions. The long saphenous vein and the femoral and popliteal vessels were preserved. The distal popliteal, posterior tibial, and anterior tibial vessels were identified and preserved (Fig. 3a). The popliteal artery was divided proximal to its trifurcation, allowing removal of the leg distal to the knee joint.

Tumor resection was completed $15 \mathrm{~cm}$ from the distal end of the femur. The tibial bone flap vessels were prepared on a side table. The tibia was transected distal to the nutrient vessel at $14 \mathrm{~cm}$ from the proximal joint surface. The tibia was then inverted, reversed, and fixed with an intramedullary nail. The posterior tibial artery was anastomosed end to side to the femoral artery due to size mismatch. The popliteal vein was anastomosed end to end, to a similar sized tributary of the long saphenous vein (Fig. 3b).

The patient's immediate post-operative course was uneventful. Clinically and radiologically the flap has survived. At 3.5 years follow up the patient had no stump problems, wore prosthesis comfortably and competed at sports (Fig. 4a \& 4b), 


\section{Discussion:}

Overgrowth is one of the most frequent complications following amputation in children, occurring in $4 \%$ to $35 \%$ depending on the age of the patient and location of amputation. In a series of 109 children who underwent transmetaphyseal or transdiaphyseal amputation, 46\% underwent at least one revision for overgrowth, and $18 \%$ required multiple revisions ${ }^{6}$. Overgrowth is more common in younger children, but can occur at any age prior to skeletal maturity. Abraham et al. found that patients who underwent amputation after the age of 12 did not require revision surgery ${ }^{5}$. Other series, however, have documented overgrowth requiring revision in children 12 and over, albeit less commonly ${ }^{3,17}$. For the two adolescents in our series undergoing primary amputation, aged 10 and 12, we elected to cap the amputation stump because of this risk.

The pathophysiology of terminal osseous overgrowth remains poorly understood. It has been suggested that periosteal and/or endosteal abnormalities, endochondral ossification, heterotopic ossification, and metaplasia of fibrous tissue are responsible 4,5 . Initial attempts at preventing overgrowth focused on proximal epiphysiodesis in the belief that this growth centre was a driver of distal overgrowth ${ }^{18}$. Later work in humans and animals has recognized that the distal osteotomy site is the primary cause of overgrowth due to woven bone being deposited on the original cortical bone, leading to the described soft tissue problems ${ }^{2,19,20}$.

Many approaches have been taken in treating this problem, with some form of "capping" of the bone end after debridement of the overgrowth proving most efficacious. It is thought that by occluding the medullary canal and distal aspect of the bone, overgrowth is inhibited by preventing communication between external mediators and bone marrow elements and endosteum ${ }^{4}$. This approach was first described in the late 1960's by Swanson who used a heatmoulded, intramedullary stemmed and collared silicone implant which is sutured to the bone. Swanson described a cohort of fourteen children who had undergone multiple revision procedures for terminal bony overgrowth. Although the series showed a reduction in the rates of overgrowth, the number of complications was high with infection, skin breakdown and implant fracture seen in $50 \%$ of cases 7,21 .

Later work by Meyer et al. looked at using a porous polyethylene cap, which they postulated would allow for bony ingrowth and therefore better retention. In 6 children with a mean of 14 months follow up they showed good short-term results, but longer term had the same complications as silicon with fracture of the implant, extrusion and infection ${ }^{22}$. Tenholder et al. described their experience using PTFE felt caps in 17 cases of established overgrowth. Mean follow-up was 4 years 9 months. They compared their results with historical control groups undergoing simple excision and showed a revision rate of $29 \%$ with PTFE caps compared to $86 \%$ in the control group ${ }^{8}$.

Despite the obvious advantages of synthetic caps, the complication rates led to investigation of the use of autologous materials. In 1974 Marquardt introduced cap-plasty of the stump using an autologous cartilage-bone graft to bear weight and to prevent overgrowth and skin penetration ${ }^{23,24}$. The goal being conversion of a transosseous amputation into a stump resembling that seen in a 
disarticulation. A number of different sources of autologous graft have subsequently been described including iliac crest wedges, head of fibula, and various bone segments from the amputated limbs 4,10-12. The majority of described treatments use non-vascularised bone grafts despite the incidence of bony union being higher, with less need for revision surgery, utilising vascularised bone flaps.

Bernd et al. had a revision rate of $12 \%$ ( 6 of 50 limbs) with autologous bone "cap-plasties" performed for the treatment of established overgrowth following amputations. Follow up was for a mean of 7 years. A variety of graft sources were used including iliac crest, fibular head and talus ${ }^{12}$. Davids et al. looked at their results over a 31-year period where treatment of overgrowth evolved from simple excision to synthetic capping to autologous capping with non-vascularised iliac crest. They showed a decrease from $84 \%$ revision rate in resection group, to $77 \%$ in the synthetic cap group and ultimately a $30 \%$ revision rate in the iliac crest group 4.

Using a rabbit model of amputation Wang et al. showed that capping with a metatarsal epiphysis reduced the rate of overgrowth from $80 \%$ in the control group to $0 \%$ in the epiphyseal transfer group ${ }^{20}$. Subsequent clinical work has also shown good results with non-vascularised epiphyseal transfer. Benevenia et al. showed an overgrowth rate of $10 \%(1 / 10)$ of primary amputations for tumor with use of a prophylactic epiphyseal transplant from the amputated segment 11 . They compared these results with a control group in their institution who had an $86 \%$ overgrowth rate. In most patients the first metatarsal epiphysis was used, with the distal fibula also being used in a few cases. A larger study by Fedorak et al. also showed a bony overgrowth rate of $10 \%$ following proximal fibular epiphysis grafting to treat overgrowth of the tibia.

Free epiphyseal transfer to maintain growth was first attempted in the late $19^{\text {th }}$ century. Results with this technique remained disappointing, with limited growth and early closure of the growth plate until the advent of microvascular transfer with early studies demonstrating that growth could be maintained when the blood supply to the growth plate was preserved 25-28. Weber described a new technique of stump capping of the lower leg in two patients with congenital pseudoarthrosis of the tibia where all neurovascular structures supplying the calcaneus are carefully maintained and subsequently, the tibia and fibula are inserted into the calcaneus. With 5 years of follow up no overgrowth was seen ${ }^{10}$.

Using this knowledge we elected, when possible, to provide paediatric patients undergoing transosseous amputations with vascularised epiphyseal stump capping. Using a vascularized flap rather than a non-vascularized graft allowed us to use larger bone segments, when indicated, to preserve length, to include vascularized soft tissue cover in the form of fillet of sole flap as well as talus in one patient, and to potentially preserve growth with a vascularized epiphysis. In all the prophylactic cases the concept of "spare parts" surgery was used, therefore limiting donor site morbidity, as what was used would have otherwise been discarded with the amputation specimen. Only one patient required any revision surgery with a mean follow-up of 6.5 years. In this case the distal tibial epiphysis had been preserved and he underwent medial distal tibial hemi-epiphyseodesis as the medial malleous was becoming prominent. He also underwent removal of prominent screws at the same time. 
We believe this to be the first reported case series describing the use of vascularized bone flaps to prevent stump spiking with medium and long term follow up.

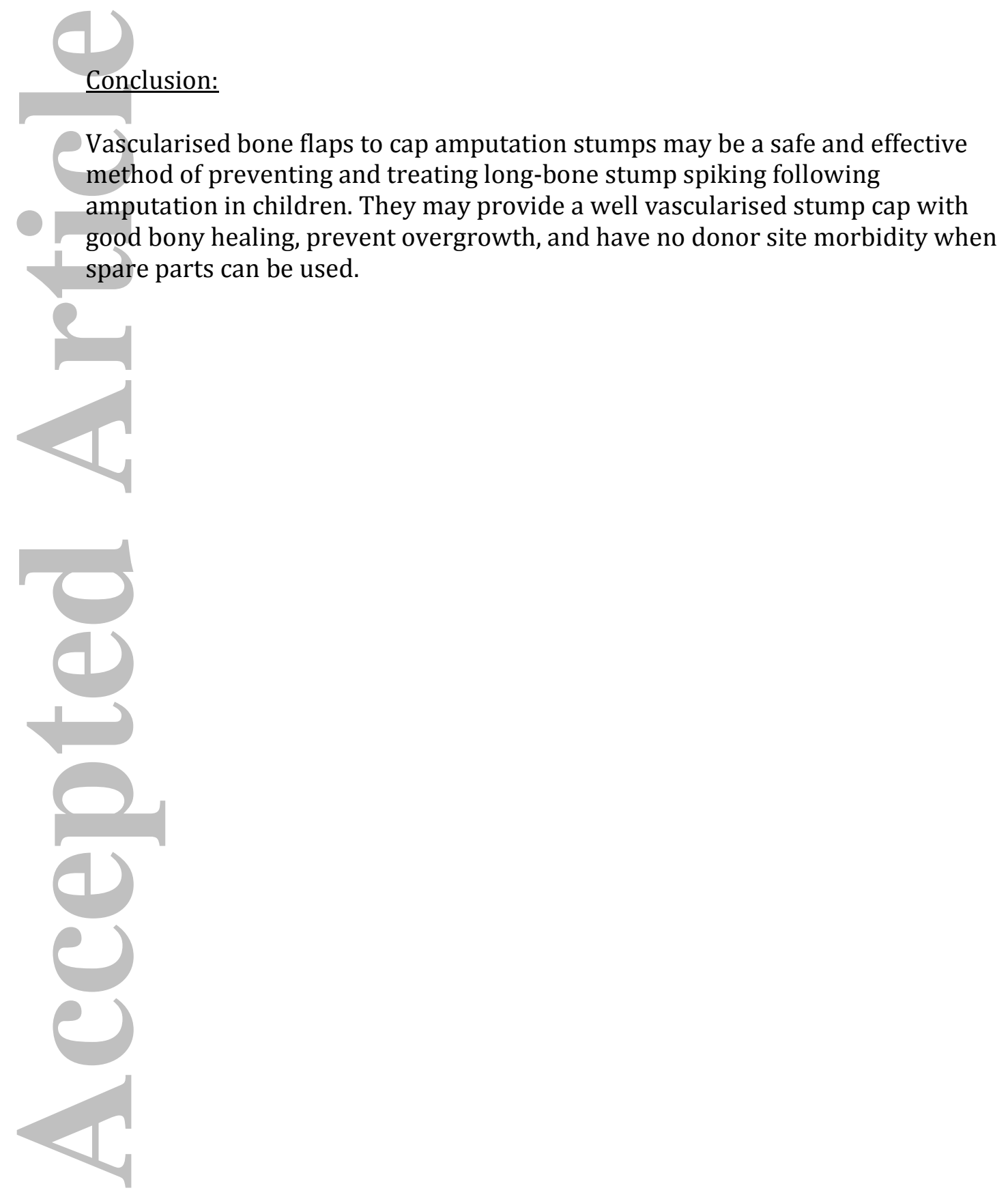




\section{$\underline{\text { References: }}$}

1. Aitken G, Frantz C. The juvenile amputee. J Bone Joint Surg Am. 1953;35A:659-64

Aitken G. Surgical Amputation in Children. J Bone Joint Surg Am.

1963;45:1735-41

3. Jorring K. Amputation in children. A follow-up of 74 children whose lower extremities were amputated. Acta Orthop Scand. 1971;42:178-186

4. Davids JR, Meyer LC, Blackhurst DW. Operative treatment of bone overgrowth in children who have an acquired or congenital amputation. J Bone Joint Surg Am. 1995;77:1490-1497

5. Abraham E, Pellicore RJ, Hamilton RC, Hallman BW, Ghosh L. Stump overgrowth in juvenile amputees. J Pediatr Orthop. 1986;6:66-71 O'Neal ML, Bahner R, Ganey TM, Ogden JA. Osseous overgrowth after amputation in adolescents and children. J Pediatr Orthop. 1996;16:78-84 Swanson AB. Silicone-Rubber Implants to Control the Overgrowth Phenomenon in the Juvenile Amputee. Inter-Clin Inf Bull. 1972;11:5-8 Tenholder M, Davids JR, Gruber HE, Blackhurst DW. Surgical management of juvenile amputation overgrowth with a synthetic cap. J Pediatr Orthop. 2004;24:218-226

9. Drvaric DM, Kruger LM. Modified Ertl osteomyoplasty for terminal overgrowth in childhood limb deficiencies. J Pediatr Orthop. 2001;21:392394

10. Weber M. Neurovascular calcaneo-cutaneus pedicle graft for stump capping in congenital pseudarthrosis of the tibia: preliminary report of a new technique. J Pediatr Orthop B. 2002;11:47-52

11. Benevenia J, Makley JT, Leeson MC, Benevenia K. Primary epiphyseal transplants and bone overgrowth in childhood amputations. J Pediatr Orthop. 1992;12:746-50

12. Bernd L, Bläsius K, Lukoschek M, Lücke R. The autologous stump plasty. Treatment for bony overgrowth in juvenile amputees. J Bone Joint Surg Br. 1991;73:203-206

13. Marquardt E, Correll J. Amputations and prostheses for the lower limb. Int Orthop. 1984;8:139-46

14. Al-Jabri T, Mannan A, Giannoudis P. The use of the free vascularised bone graft for nonunion of the scaphoid: a systematic review. J Orthop Surg Res. 2014;9:21

15. Foster RD, Anthony JP, Sharma A, Pogrel MA. Vascularized bone flaps versus nonvascularized bone grafts for mandibular reconstruction: an outcome analysis of primary bony union and endosseous implant success. Head Neck. 1999;21:66-71

16. Tetik C, Başar H, Bezer M, Erol B, Ağir I, Esemenli T. Comparison of early results of vascularized and non-vascularized fibular grafting in the treatment of osteonecrosis of the femoral head. Acta Orthop Traumatol Turc. 2011;45:326-34

17. Benevenia J, Makley JT, Leeson MC, Benevenia K. Primary epiphyseal transplants and bone overgrowth in childhood amputations. J Pediatr Orthop. 1992;12:746-50

18. VomSaal F. EPIPHYSIODESIS COMBINED WITH AMPUTATION. J Bone Jt 
Surg Am. 1939;21:442-443

19. Speer DP. The pathogenesis of amputation stump overgrowth. Clin Orthop Relat Res. 1981:294-307

20. Wang GJ, Baugher WH, Stamp WG. Epiphyseal transplant in amputations. Effects on overgrowth in a rabbit model. Clin Orthop Relat Res. 1978:2858

21. Swanson AB. Bone Overgrowth In The Juvenile Amputee And Its Control By The Use Of Silicone Rubber Implants. Inter-Clin Inf Bull. 1969;8:9-19

22. Meyer LC, Sauer BW. The Use of Porous, High-Density Polyethylene Caps in the Prevention of Appositional Bone Growth in the Juvenile Amputee: A Preliminary Report. Inter-Clin Inf Bull. 1975;14:1-5

23. Marquardt E. Plastiche operationen bei drohender konchendurchspiessungamkindlichen oberarmstumpf. Eine vorlaue mitteilung. Zeitschr Orthop. 1976;114:711-714

24. Pfeil J, Marquardt E, Holtz T, Niethard FU, Schneider E, Carstens C. The stump capping procedure to prevent or treat terminal osseous overgrowth. Prosthet Orthot Int. 1991;15:96-9

25. Tsai TM, Ludwig L, Tonkin M. Vascularized Fibular Epiphyseal Transfer. A Clinical Study. Clinical orthopaedics and related research, 228-234 (1986). doi:10.1097/01241398-198703000-00045

26. Pho RW, Patterson MH, Kour a K, Kumar VP. Free Vascularised Epiphyseal Transplantation in Upper Extremity Reconstruction. Journal of hand surgery (Edinburgh, Scotland) 13, 440-447 (1988). doi:10.1016/02667681(88)90175-1

27. Taylor GI, Wilson KR, Rees MD, Corlett RJ, Cole WG. The anterior tibial vessels and their role in epiphyseal and diaphyseal transfer of the fibula: experimental study and clinical applications. Br J Plast Surg. 1988;41:451469

28. Innocenti M, Ceruso M, Manfrini $\mathrm{M}$, et al. Free vascularized growth-plate transfer after bone tumor resection in children. J Reconstr Microsurg. 1998;14:137-143 


\section{$\underline{\text { Figure Legends }}$}

Fig. 1 Illustration of the reconstruction with preoperative anatomy, and technicalities of the procedure with emphasis on the microvascular anastomoses, intramedullary fixation. Of note the venous drainage of the flap was in an antegrade direction but arterial flow was in a retrograde direction via the distal end of the posterior tibial artery.

Fig. 2a, 2b \& 2c. (a) Lympho-venous malformation of the hand prior to amputation. (b) Immediate post-operative x-ray of the distal radius used to cap the amputation stump. (c) X-ray 1 year post-operatively showed $6 \mathrm{~mm}$ growth of the radius from the distal epiphysis with no signs of bony overgrowth.

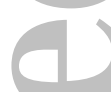

Fig. 3a \& 3b. Photograph of (a) the prepared flap. The ruler shows $14 \mathrm{~cm}$ of tibia with green arrows depicting the popliteal vessels just proximal to trifurcation and the posterior tibia vessels at the level of the tibial osteotomy. (b) the inset flap after intra-meduallary nail fixation. The arterial (cranial) and venous (caudal) anastomoses are indicated by the tips of the surgical instruments.

Fig. 4a \& 4b. Immediate post-operative x-ray of the proximal tibia used to cap the femoral amputation stump. X-ray 3.5 year post-operatively showed $25 \mathrm{~mm}$ growth of the distal bone and no signs of bony overgrowth. 
Table 1. Patient demographics
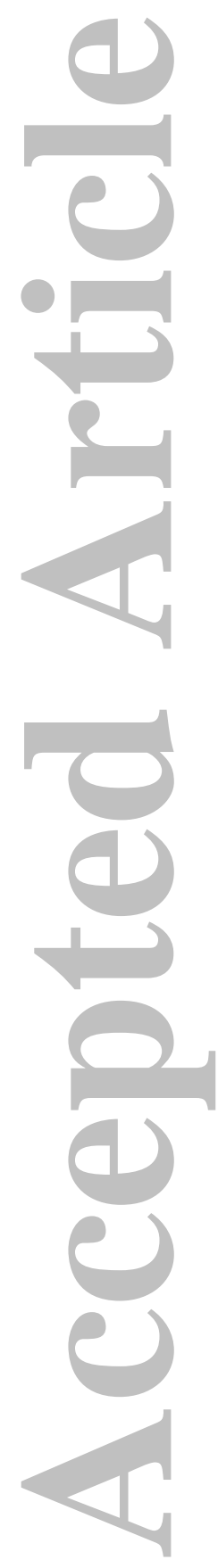

John Wiley \& Sons

This article is protected by copyright. All rights reserved. 


\begin{tabular}{|c|c|c|c|c|c|c|c|c|c|c|}
\hline $\begin{array}{l}\mathrm{Pa} \\
\text { tie } \\
\mathrm{nt}\end{array}$ & $\begin{array}{c}\text { Age at } \\
\text { Index } \\
\text { Procedure } \\
\text { (years) }\end{array}$ & Sex & Site & Diagnosis & Flap Used & $\begin{array}{l}\text { Flap } \\
\text { size }\end{array}$ & $\begin{array}{c}\text { Donor } \\
\text { Vessels I } \\
\text { Pedicle }\end{array}$ & $\begin{array}{c}\text { Post-Op } \\
\text { Complicatio } \\
n\end{array}$ & 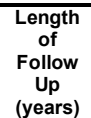 & $\begin{array}{c}\text { Final } \\
\text { Outcome }\end{array}$ \\
\hline 1 & 12 & Female & $\begin{array}{l}\text { Tibia/Fibul } \\
\text { a }\end{array}$ & Trauma & $\begin{array}{l}\text { Free } \\
\text { vascularised } \\
\text { calcaneus }\end{array}$ & $\begin{array}{l}2 \times 2 \\
\mathrm{~cm}\end{array}$ & $\begin{array}{l}\text { Posterior } \\
\text { Tibial artery + } \\
\text { venae } \\
\text { commitans }\end{array}$ & $\begin{array}{l}\mathrm{Nil}- \\
\text { radiological } \\
\text { posterior } \\
\text { spike } \\
\text { clinically } \\
\text { undetectable }\end{array}$ & 16 & $\begin{array}{l}\text { Good } \\
\text { function, } \\
\text { no stump } \\
\text { problems }\end{array}$ \\
\hline 2 & 10 & Male & $\begin{array}{l}\text { Tibia/Fibul } \\
\text { a }\end{array}$ & $\begin{array}{l}\text { Arterial } \\
\text { Thrombosis }\end{array}$ & $\begin{array}{l}\text { Pedicled } \\
\text { distal tibial } \\
\text { epiphysis + } \\
\text { metaphysis }\end{array}$ & $\begin{array}{l}5 \times 2 \\
\mathrm{~cm}\end{array}$ & $\begin{array}{l}\text { Posterior } \\
\text { Tibial artery + } \\
\text { venae } \\
\text { commitans }\end{array}$ & Nil & 7 & $\begin{array}{l}\text { Good } \\
\text { function, } \\
\text { no stump } \\
\text { problems }\end{array}$ \\
\hline 3 & 7 & Male & Fibula & Trauma & $\begin{array}{l}\text { Pedicled } \\
\text { Talus }\end{array}$ & $\begin{array}{l}3 \mathrm{x} \\
1.5 \\
\mathrm{~cm}\end{array}$ & $\begin{array}{l}\text { Posterior } \\
\text { Tibial artery + } \\
\text { venae } \\
\text { commitans }\end{array}$ & $\begin{array}{l}\text { Removal } \\
\text { screws + } \\
\text { epiphyseodes } \\
\text { is }\end{array}$ & 5 & $\begin{array}{l}\text { Good } \\
\text { function, } \\
\text { no stump } \\
\text { problems }\end{array}$ \\
\hline 4 & 9 & Female & Femur & $\begin{array}{l}\text { Osteosarcom } \\
\text { a }\end{array}$ & $\begin{array}{l}\text { Free } \\
\text { Proximal } \\
\text { Tibial } \\
\text { Epiphysis + } \\
\text { Metaphysis }\end{array}$ & $\begin{array}{l}14 \times 2 \\
\mathrm{~cm}\end{array}$ & $\begin{array}{l}\text { Femoral } \\
\text { artery + } \\
\text { Popliteal vein }\end{array}$ & Nil & 3.5 & $\begin{array}{l}\text { Good } \\
\text { function, } \\
\text { no stump } \\
\text { problems }\end{array}$ \\
\hline 5 & 8 & Male & $\begin{array}{l}\text { Radius/UIn } \\
\text { a }\end{array}$ & $\begin{array}{l}\text { Lymphatic- } \\
\text { Venous } \\
\text { Malformation }\end{array}$ & $\begin{array}{l}\text { Pedicled } \\
\text { Radius } \\
\text { Epiphysis + } \\
\text { Metaphysis }\end{array}$ & $\begin{array}{l}2.5 \mathrm{x} \\
1.2 \\
\mathrm{~cm}\end{array}$ & $\begin{array}{l}\text { Radial + } \\
\text { Anterior } \\
\text { Interosseous } \\
\text { arteries + } \\
\text { venae } \\
\text { commitans }\end{array}$ & Nil & 4 & $\begin{array}{l}\text { Good } \\
\text { function, } \\
\text { no stump } \\
\text { problems }\end{array}$ \\
\hline 6 & 13 & Male & $\begin{array}{l}\text { Tibia/Fibul } \\
\text { a }\end{array}$ & Trauma & $\begin{array}{l}\text { Free } \\
\text { Scapular } \\
\text { angle }+ \\
\text { Latisimus } \\
\text { Dorsi flap }\end{array}$ & $\begin{array}{l}2 \mathrm{x} \\
1.5 \\
\mathrm{~cm}\end{array}$ & $\begin{array}{l}\text { Posterior } \\
\text { Tibial artery + } \\
\text { venae } \\
\text { commitans }\end{array}$ & Nil & 4 & $\begin{array}{l}\text { Good } \\
\text { function, } \\
\text { no stump } \\
\text { problems }\end{array}$ \\
\hline
\end{tabular}



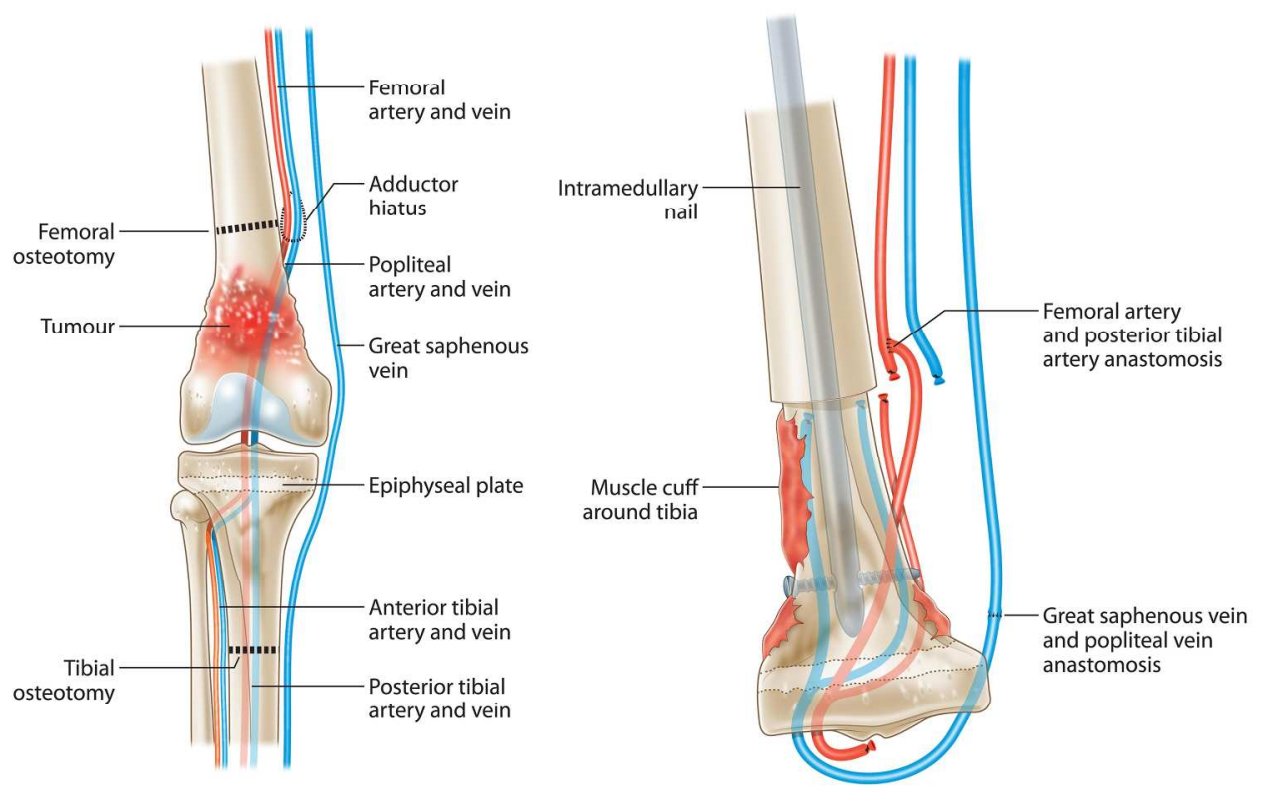

Fig. 1 Illustration of the reconstruction with preoperative anatomy, and technicalities of the procedure with emphasis on the microvascular anastomoses \& intramedullary fixation. Of note the venous drainage of the flap was in an antegrade direction but arterial flow was in a retrograde direction via the distal end of the posterior tibial artery.

$214 \times 142 \mathrm{~mm}(300 \times 300 \mathrm{DPI})$

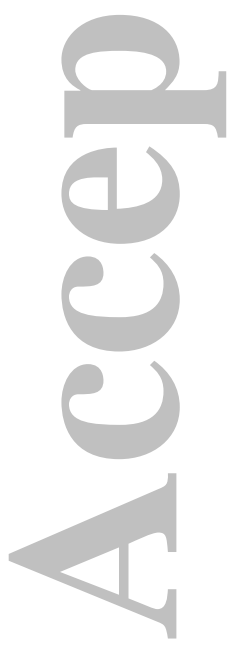




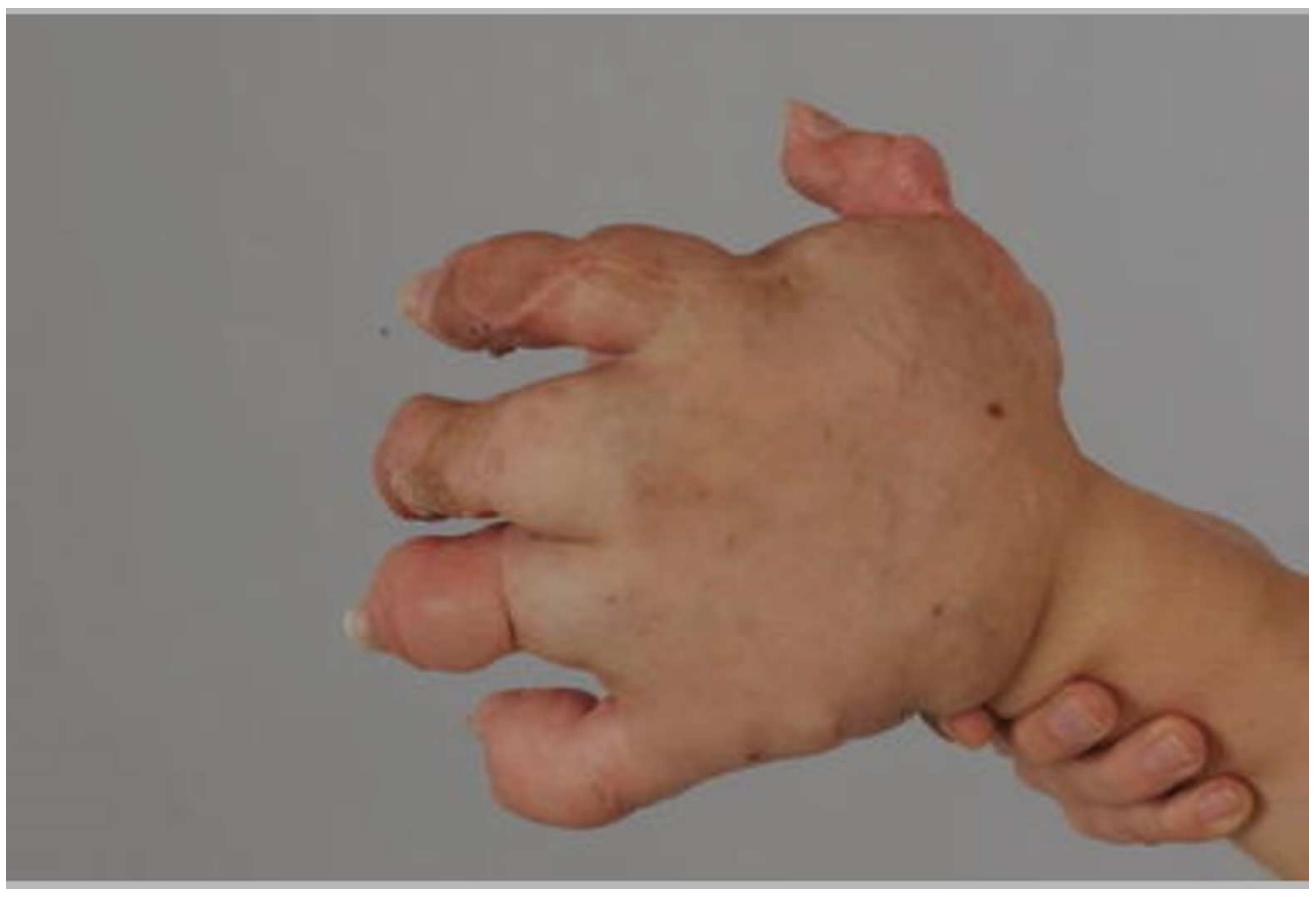

Fig. 2a, 2b \& 2c. (a) Lympho-venous malformation of the hand prior to amputation. (b) Immediate postoperative x-ray of the distal radius used to cap the amputation stump. (c) X-ray 1 year post-operatively showed $6 \mathrm{~mm}$ growth of the radius from the distal epiphysis with no signs of bony overgrowth.

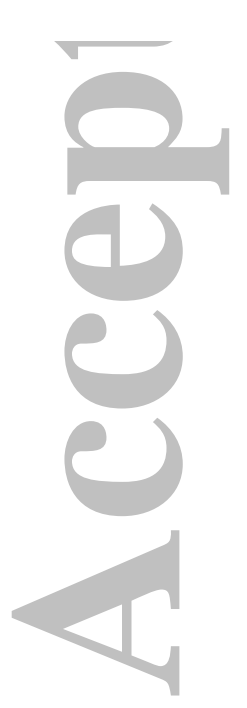

$135 \times 91 \mathrm{~mm}(144 \times 144$ DPI $)$ 


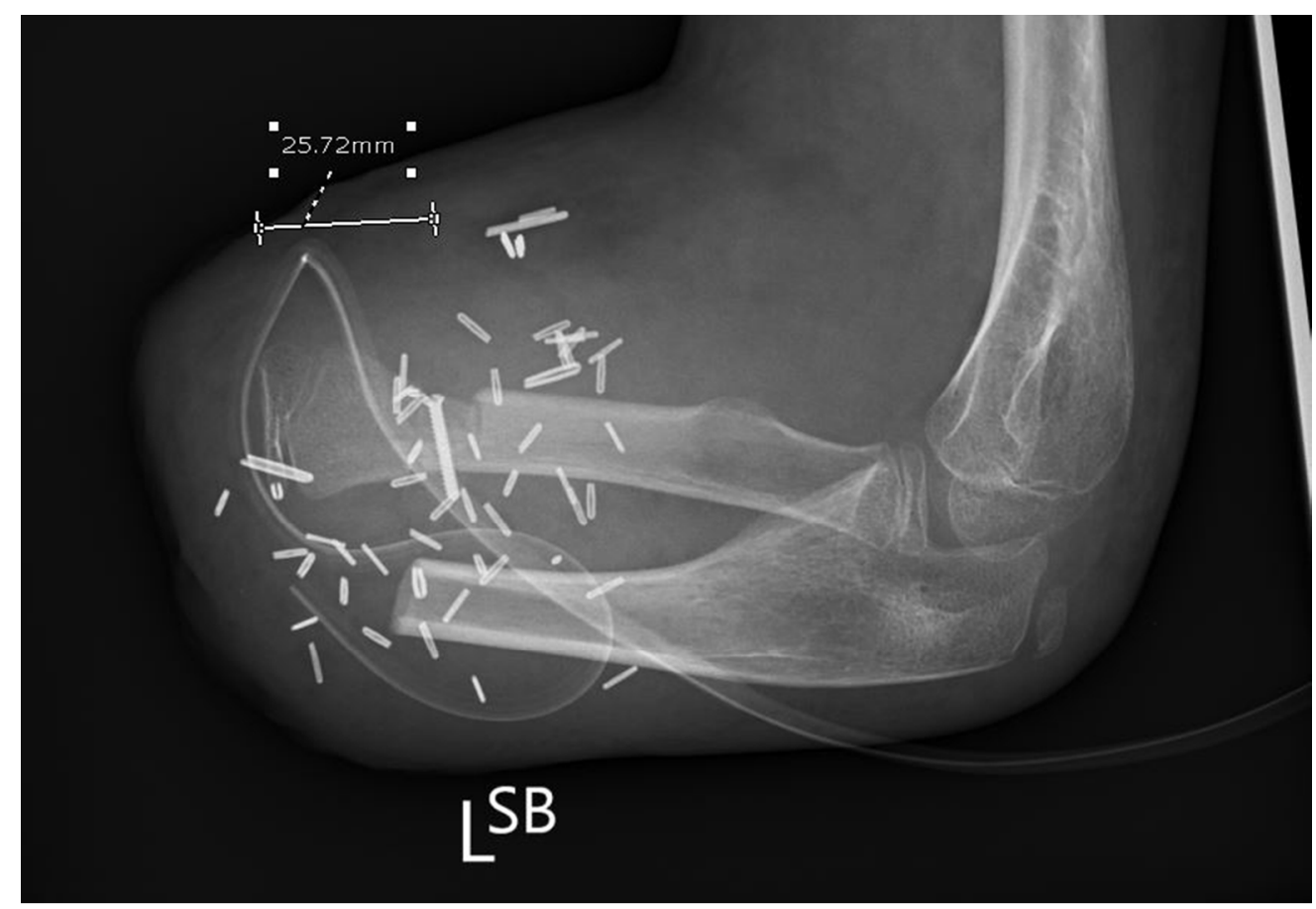

Fig. 2a, 2b \& 2c. (a) Lympho-venous malformation of the hand prior to amputation. (b) Immediate postoperative $\mathrm{x}$-ray of the distal radius used to cap the amputation stump. (c) X-ray 1 year post-operatively showed $6 \mathrm{~mm}$ growth of the radius from the distal epiphysis with no signs of bony overgrowth.

$223 \times 153 \mathrm{~mm}(96 \times 96 \mathrm{DPI})$

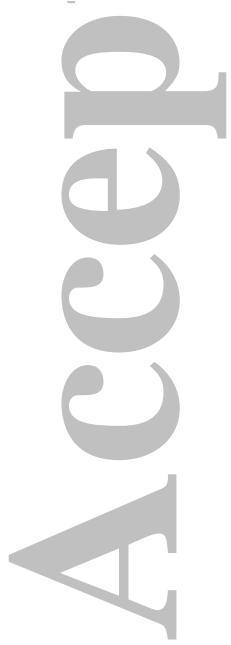




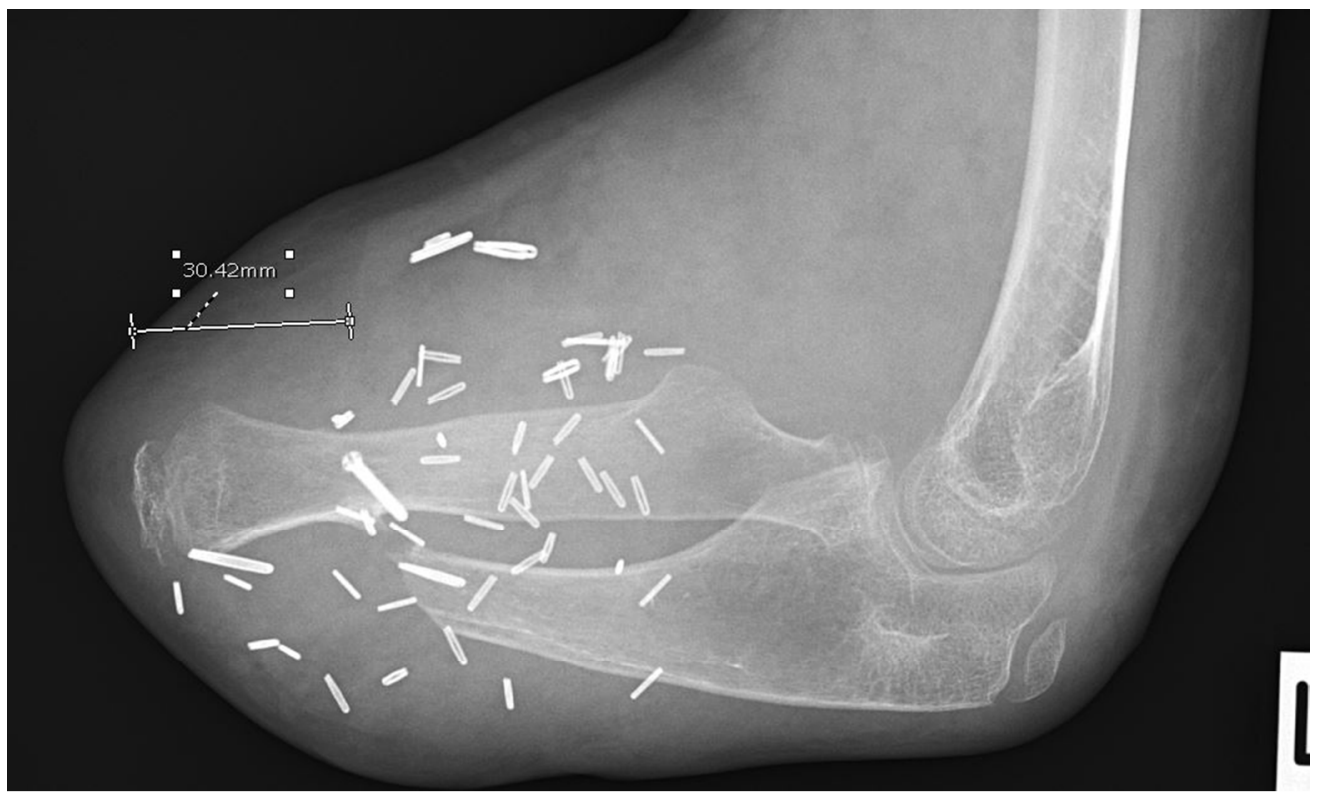

Fig. 2a, 2b \& 2c. (a) Lympho-venous malformation of the hand prior to amputation. (b) Immediate postoperative $\mathrm{x}$-ray of the distal radius used to cap the amputation stump. (c) X-ray 1 year post-operatively showed $6 \mathrm{~mm}$ growth of the radius from the distal epiphysis with no signs of bony overgrowth.

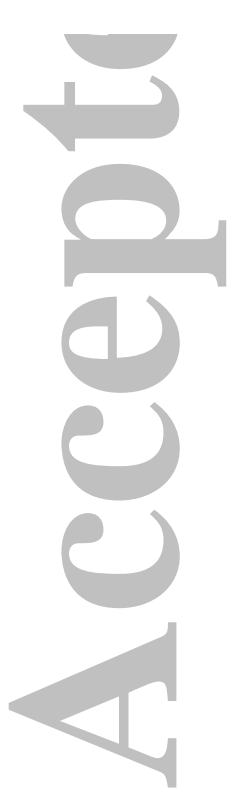

$274 \times 164 \mathrm{~mm}(96 \times 96 \mathrm{DPI})$ 


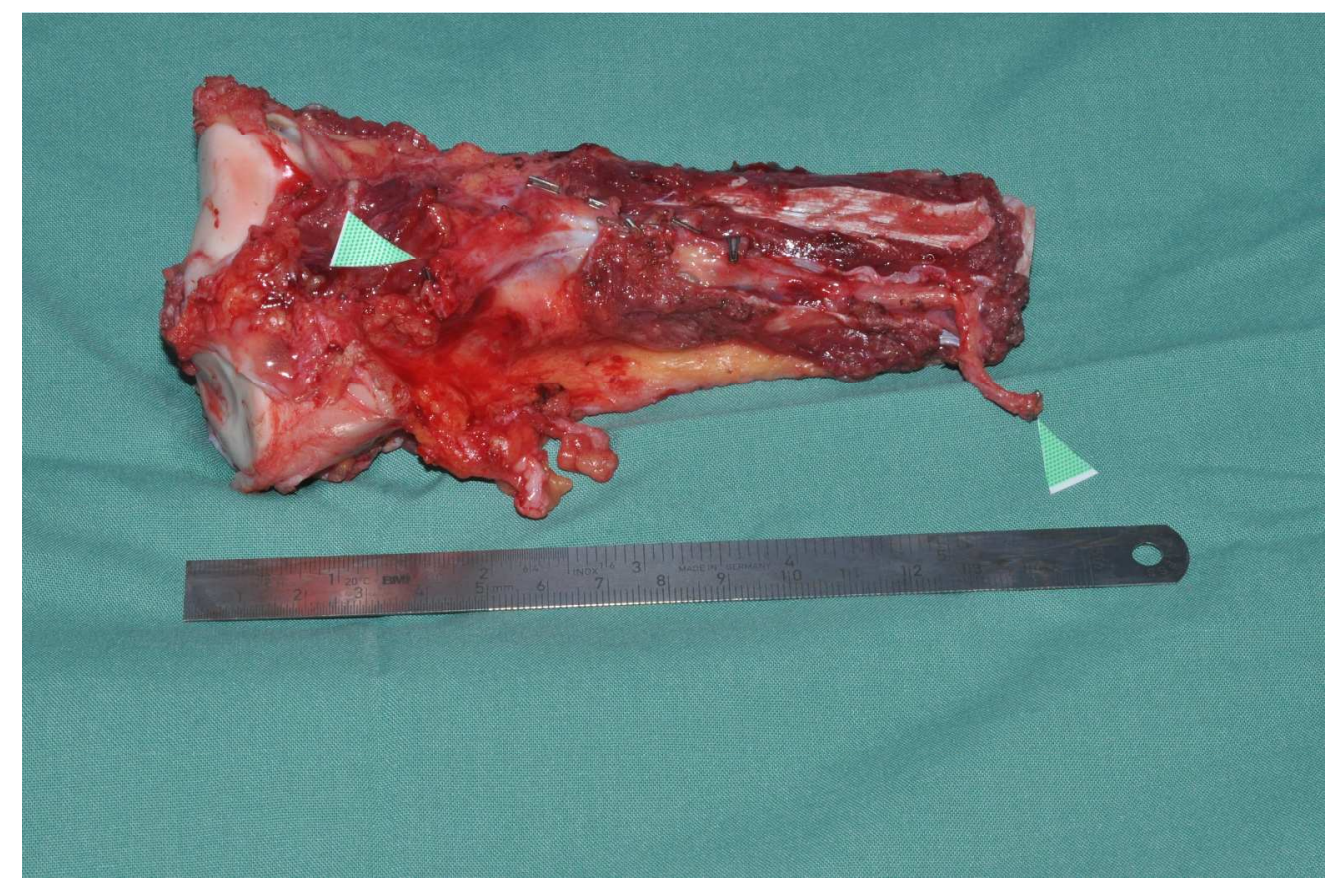

Fig. 3a \& 3b. Photograph of (a) the prepared flap. The ruler shows $14 \mathrm{~cm}$ of tibia with green arrows depicting the popliteal vessels just proximal to trifurcation and the posterior tibia vessels at the level of the tibial osteotomy. (b) the inset flap after intra-meduallary nail fixation. The arterial (cranial) and venous (caudal) anastomoses are indicated by the tips of the surgical instruments.

$241 \times 160 \mathrm{~mm}(300 \times 300$ DPI)

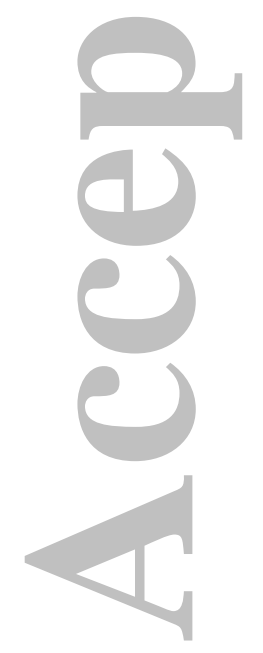




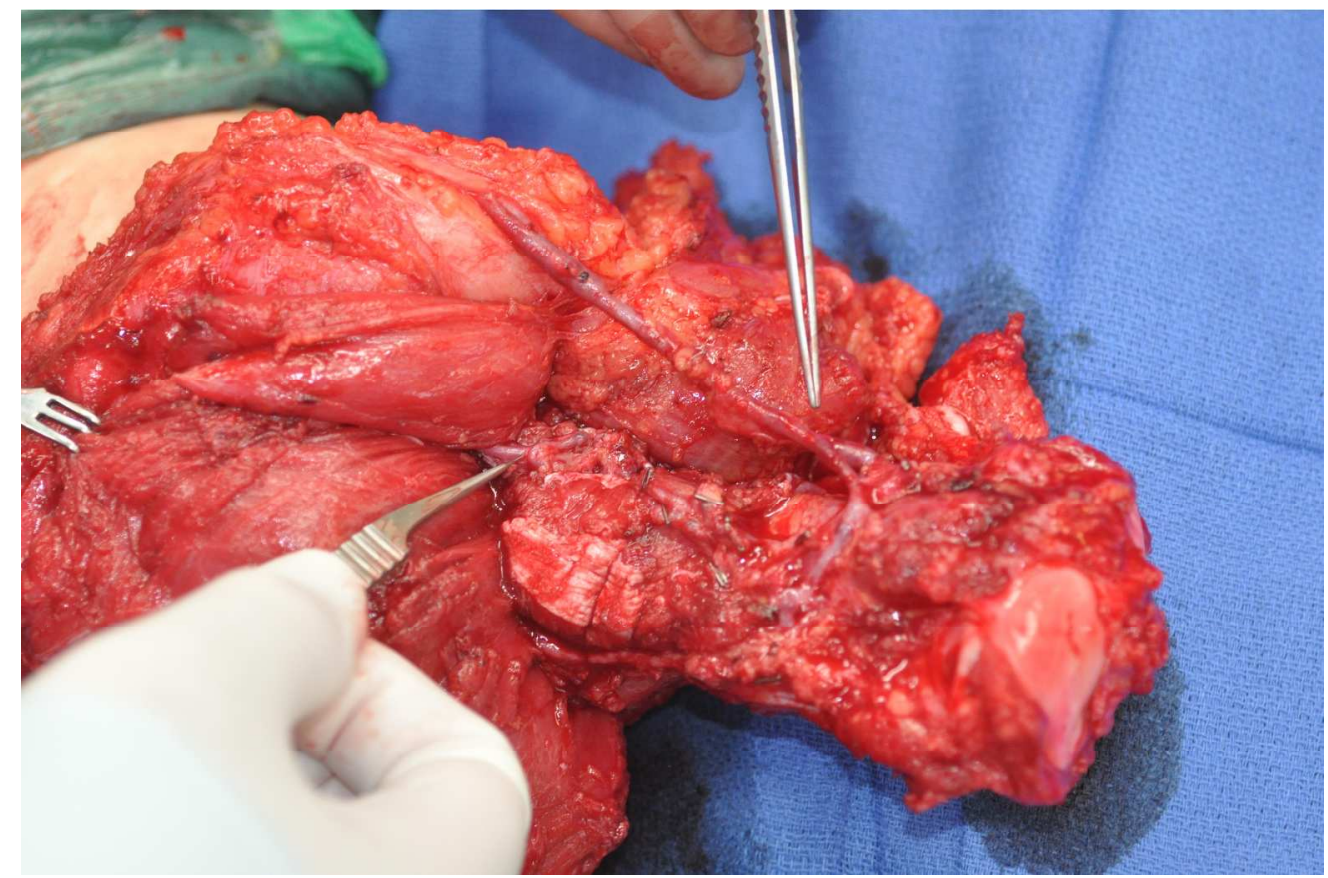

Fig. 3a \& 3b. Photograph of (a) the prepared flap. The ruler shows $14 \mathrm{~cm}$ of tibia with green arrows depicting the popliteal vessels just proximal to trifurcation and the posterior tibia vessels at the level of the tibial osteotomy. (b) the inset flap after intra-meduallary nail fixation. The arterial (cranial) and venous (caudal) anastomoses are indicated by the tips of the surgical instruments.

$$
241 \times 160 \mathrm{~mm} \text { ( } 300 \times 300 \text { DPI) }
$$

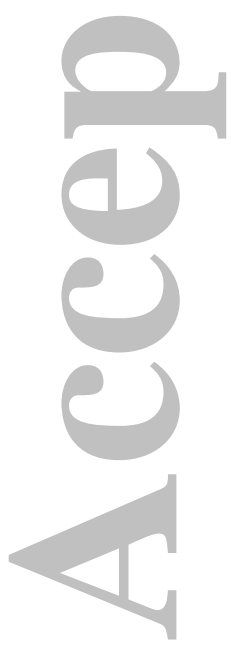




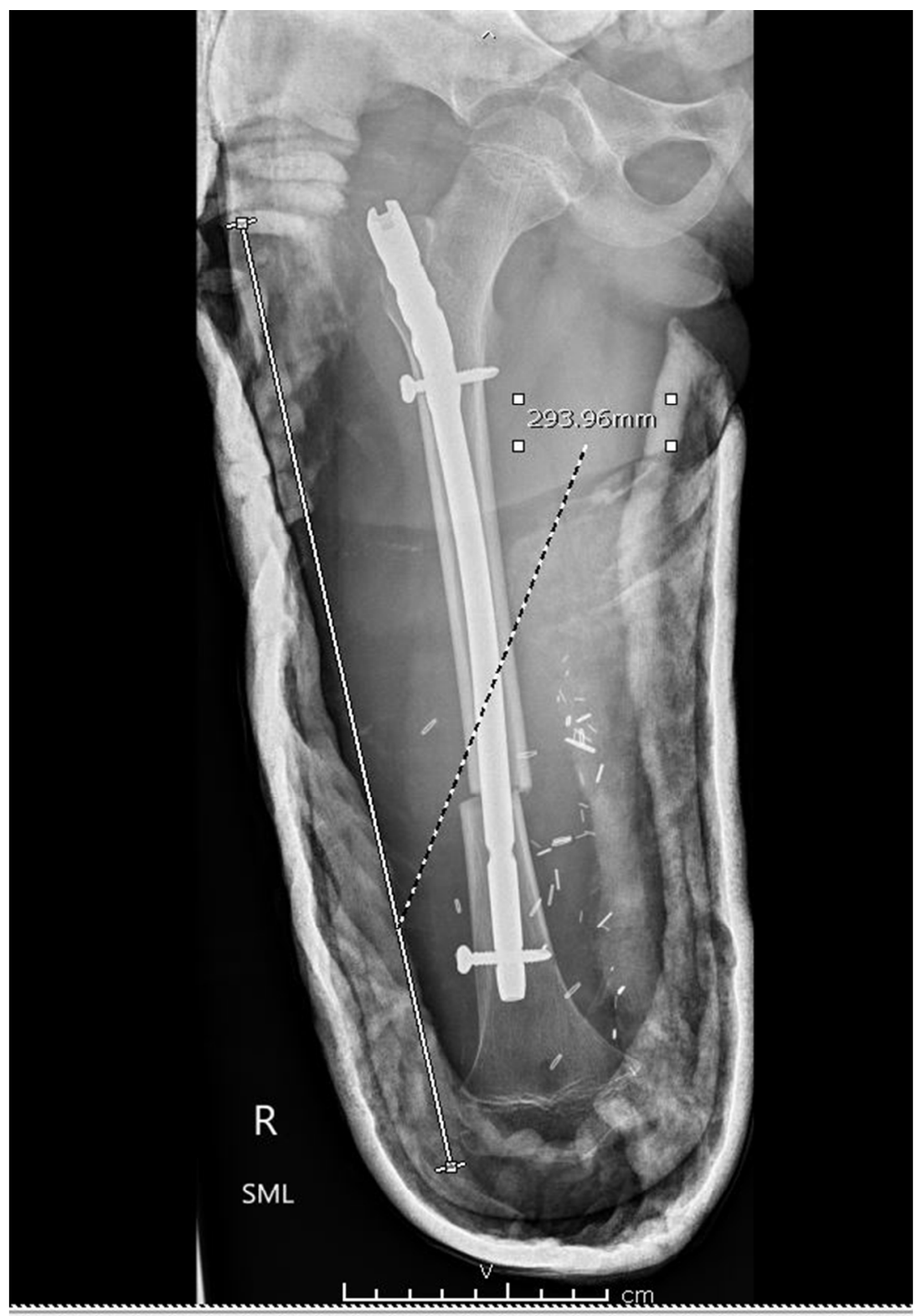

Fig. $4 a \& 4$ b. Immediate post-operative $x$-ray of the proximal tibia used to cap the femoral amputation stump. X-ray 3.5 year post-operatively showed $25 \mathrm{~mm}$ growth of the distal bone and no signs of bony overgrowth.

$156 \times 226 \mathrm{~mm}(96 \times 96 \mathrm{DPI})$ 


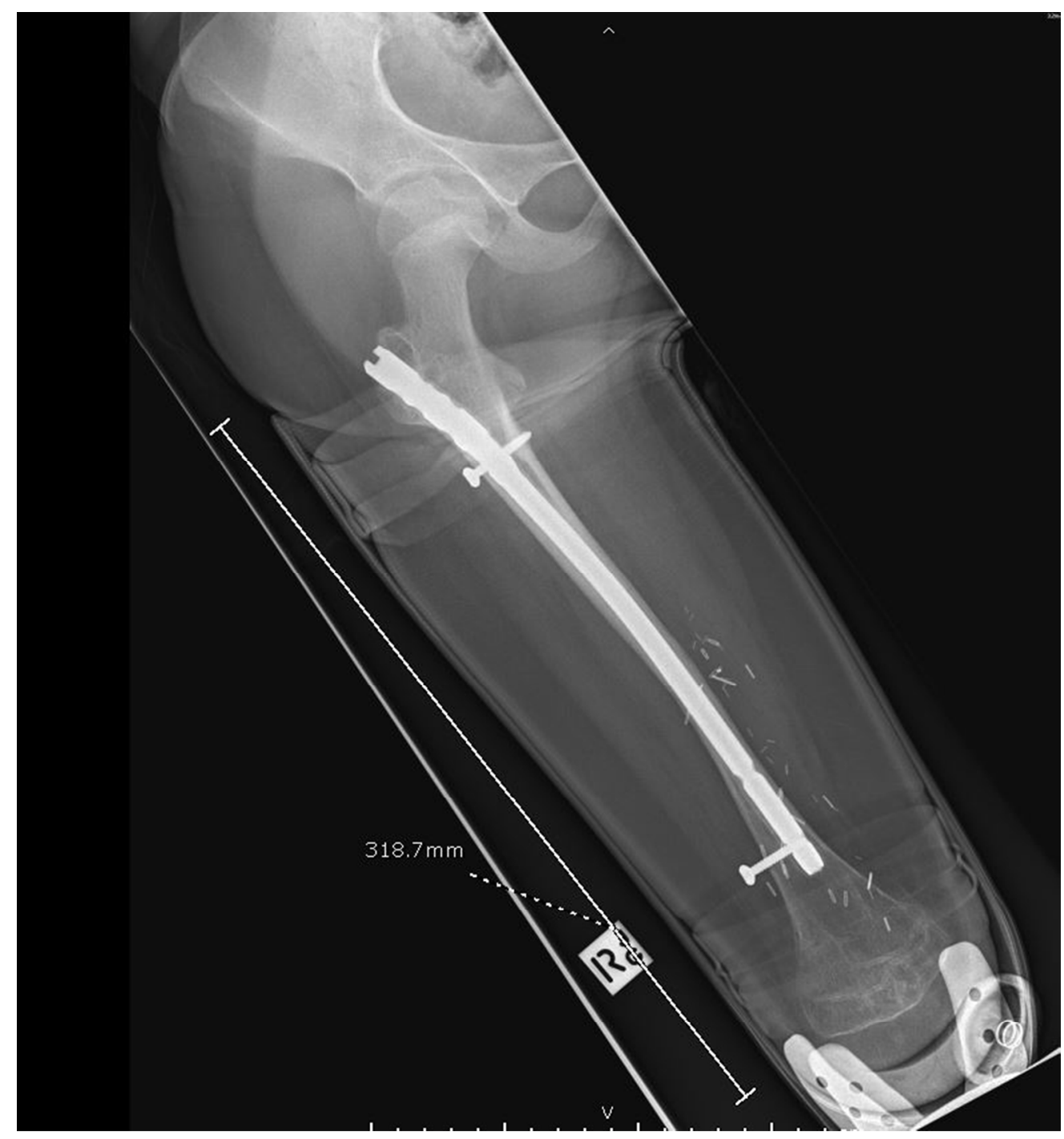

Fig. 4a \& 4b. Immediate post-operative x-ray of the proximal tibia used to cap the femoral amputation stump. X-ray 3.5 year post-operatively showed $25 \mathrm{~mm}$ growth of the distal bone and no signs of bony overgrowth.

$206 \times 221 \mathrm{~mm}(96 \times 96 \mathrm{DPI})$

John Wiley \& Sons

This article is protected by copyright. All rights reserved. 


\section{University Library}

\section{- M M N E R VA A gateway to Melbourne's research publications}

Minerva Access is the Institutional Repository of The University of Melbourne

Author/s:

Murphy, AD;Atkins, SE;Thomas, DJ;McCombe, D;Coombs, CJ

Title:

The use of vascularised bone capping to prevent and treat amputation stump spiking in the paediatric population

Date:

2017-09-01

Citation:

Murphy, A. D., Atkins, S. E., Thomas, D. J., McCombe, D. \& Coombs, C. J. (2017). The use of vascularised bone capping to prevent and treat amputation stump spiking in the paediatric population. MICROSURGERY, 37 (6), pp.589-595. https://doi.org/10.1002/ micr.30160.

Persistent Link:

http://hdl.handle.net/11343/292361 